\title{
Success Factors in Distance Education: A Case of Master of Construction Management at East Carolina University
}

\section{Prof. Syed Mahmood Ahmed P.E., East Carolina University}

Dr. Syed M. Ahmed is Professor and Chairperson of the Department of Construction Management at East Carolina University in Greenville, North Carolina USA. Prior to that, he was an Associate Professor and Graduate Program Director in the Department of Construction Management, College of Engineering \& Computing, Florida International University (FIU) and an affiliated faculty of the Department of Civil \& Environmental Engineering at FIU. Dr. Ahmed received his Ph.D. in 1993 and his MSCE in 1989 from Georgia Institute of Technology majoring in Construction Engineering \& Management, with a minor in Industrial Engineering and Management Science. He also holds an undergraduate degree of BSCE from University of Engineering \& Technology in Pakistan (1984). Dr. Ahmed has over 25 years of international experience in teaching, research and consulting in Pakistan, Hong Kong, USA, Mexico, and Jamaica. His areas of interest/expertise are construction scheduling, quality and risk management, project controls, construction safety, construction procurement, and construction education and information technology. $\mathrm{He}$ has generated substantial iexternal support and revenue from various funding agencies including United States Agency for International Development, US Department of Defense, and Florida Department of Education and through his international conferences. He is the author of four books and has also published extensively (over 150 publications) in international journals and conferences in his areas of expertise. Dr. Ahmed is currently on the editorial board of more than 6 international journals and serves as the Associate Editor of ASCE Journal of Construction Engineering \& Management and the Associate Editor of the Built Environment Project \& Asset Management (BEPAM) Journal.

\section{Ms. Kiersten Marie Mahaffy, East Carolina University}

Dr. Lincoln Harding Forbes, Harding Associates Inc., Miami

Lincoln Forbes, Ph.D., P.E., FIIE, LEED® AP lhforbes@ gmail.com

Dr. Lincoln Forbes is a subject matter expert in lean project delivery and lean management systems. A

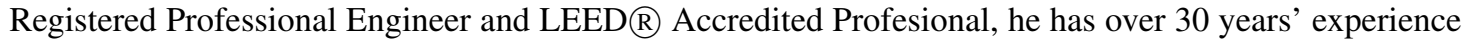
in various aspects of facilities design, construction support, and quality/performance improvement. He also serves as an adjunct professor with the Department of Construction Management at East Carolina University in Greenville, North Carolina. His other adjunct assignments have been with Drexel University's Construction Management Program as well as with Florida International University's Construction Management and Engineering Management programs. His courses at these institutions have included Lean Construction, Total Quality Management, Quality Control Systems, and Construction Productivity Improvement.

As a Principal Consultant with Harding Associates Inc., of Miami, Dr. Forbes provides lean and quality improvement solutions for the construction, service, and manufacturing industries. His book "Modern Construction: Lean Project Delivery and Integrated Practices" (Forbes and Ahmed, 2010, CRC Press), is an internationally recognized reference. He has published and presented many papers internationally on the application of lean techniques and quality initiatives in the construction environment.

In previous positions Dr. Forbes served as administrative head of several facilities-related departments and functions in Miami-Dade County Public Schools, the 4th largest school district in the USA. These positions included in-house construction, design services, construction quality control, post occupancy evaluation, project warranty services, and quality management. He also provided research and technical support on sustainability practices, commissioning, construction systems, and methods and materials to improve the quality and performance of the built environment.

Dr. Forbes is a Fellow of the Institute of Industrial Engineers (IIE), and is the founder and past president of IIE's Construction Division. His other professional memberships include The Lean Construction Institute, The American Society for Healthcare Engineering (ASHE) and The American Society For Quality (ASQ). He has served as a columnist with the ASCE publication "Leadership and Management in Engineering", 
writing on Continuous Improvement in the Construction Industry, as well as a reviewer for other ASCE publications Dr. Forbes received his Ph.D. in Industrial Engineering/ Management at the University of Miami, specializing in quality and performance improvement in the built environment. Previously, he obtained both an M.S. in Industrial Engineering and an MBA at the University of Miami. He earned a B.Sc. in Electrical Engineering at the UWI, West Indies.

Mrs. Rachel M. Robinson-Watts, East Carolina University

Ms. Ashley Lauren Gregory, East Carolina University 


\title{
Success factors in distance education: A Case of Master of Construction Management at East Carolina University
}

\begin{abstract}
Distance education has become the most significant change to the process of teaching and learning in recent decades ${ }^{21}$. A survey conducted by the U.S. National Center for Education Statistics identified more than 21 million students enrolled in distance education, while almost 3 million were enrolled in graduate courses during the fall of 2012. This research addresses the key success factors for online classes and provides recommendations on actions that institutions can take to improve the quality of online instruction programs. It includes a SWOT analysis to identify challenges and generalize strengths, weaknesses, threats and opportunities, in managing online graduate construction management courses based on the responses of a sample population. The research is based on the case study of the Master of Construction Management (MCM) program that has been offered online for the past 10 years at East Carolina University. The survey population included construction management educational professionals, current and graduated students, and new industry professionals. Data was collected from 10 survey respondents. Telephone surveys were conducted with two participants. While the relatively small sample size was dictated by cost limitations, the detailed responses provided valuable program information.

Students praised online courses for its convenience and portability, while providing a broader world view and technical depth of the construction industry. Educators cited the benefit of additional course enrollment without the obstacles that are faced with enrolling traditional face to face classes. Educators felt the need for strategies to correct negative perceptions about online programs as being of lesser quality than face-to-face classes. The cost of tuition was also cited as being an area for improvement in light of the high cost of student debt. At the same time the cost of course development and delivery was cited as a constraint for some institutions. Commitment by both the institution and the faculty were identified as key success factors in having online programs approach the quality of face-to-face programs.
\end{abstract}

\section{Key Words}

Online learning, learning environment, instructional design, face-to-face instruction

\section{Introduction}

Construction managers have typically trained "on the job" and have been elevated from the ranks into the management level without the benefit of either a college degree or education in construction management for many years ${ }^{8}$. However, there is an increasing trend for construction managers to be recruited heavily from construction management education programs. As construction projects grow in complexity, they create a demand for well-educated, trained construction managers with a sound knowledge of business and building management. These projects require advanced management skills that include innovations in technology and equipment such as Building Information Modeling (BIM). Unquestionably, the demand for 
construction management graduates has increased. Graduates typically fill entry-level positions with a variety of titles and duties in the construction industry, such as estimators, field engineers, schedulers, office engineers, project engineers and project managers ${ }^{5}$.

Online learning can be defined as the delivery of course content via electronic media ${ }^{9}$. As a result of the growth in information technology, online classes have experienced sustained and significant growth in recent decades. Distance education has become the most significant change to the process of teaching and learning ${ }^{21}$. A survey conducted by the U.S. National Center for Education Statistics identified that more than 21 million students enrolled in distance education, while almost 3 million were enrolled in graduate courses during the fall of 2012. In response to a growing demand for educational delivery universities and colleges have been utilizing the benefits of distance education, especially since the virtual classroom avoids the need for heavy investments in physical plant. Universities and colleges have responded to the needs of the market by offering degrees ranging from associates to masters, as well as certifications in specific topics such as planning, scheduling, and safety management.

There are many benefits to the online classroom environment; it is not limited by geography, as long as reliable internet access is available. The flexible nature of online instruction allows students of any age or level of experience to enroll in courses of their choosing at times that are most convenient to them. Depending on the flexibility of the respective institution students may work full-time and pursue an advanced education in the comfort of their own homes. In addition, students are able to work at their own pace, gradually transition to their new role, and develop a suitable working student lifestyle More people, within and outside of the industry, have the ability to learn more about other industry positions and the opportunity to dive deeper into their own discipline.

Given the diverse groups of people involved in online education including students, instructors, institute administrators and technical staff, there are several factors and inputs from these constituencies that affect the success of online education programs. This paper aims to address the challenges in providing graduate construction management online courses from the perspectives of both educators and students. It also investigates management practices that can be implemented to overcome challenges related to the development of course guidelines and implementation of current and future online construction management programs.

\section{Literature Review}

\section{Definition of distance education}

Distance education is an institution-based, informal education in which the learning group and instructors are physically separated; interactive telecommunications systems are used to connect learners, resources, and instructors ${ }^{19}$. Online distance learning has been widely adopted in academic institutions ${ }^{2}$. Most of the instructional activity takes place entirely online without faceto-face meeting requirements between instructors and students. Other such delivery methods

combine both web-based and print-based resources such as textbooks and workbooks ${ }^{14}$. Many 
believe that the key to success for distance education is the interaction between learner and instructor. Human-computer interaction makes the content and educational tools accessible. An important benefit of online distance learning is the 24-hour accessibility of information, up-to date contents, customizable courses, cost effectiveness, and self-paced learning. The 24-hour accessibility enhances the utility of instructional delivery, especially across geographic boundaries and time zones.

\section{Critical Success Factors for Online Distance Learning}

A review of the literature identified a number of critical success factors for online distance learning. The factors were grouped into five categories: institutional management, the learning environment, instructional design, service support, and course evaluation ${ }^{6}$. Each category is comprised of several elements.

Institutional Management

Institutional management, including management level involvement, comprises market research, program framework, operational plans and cost effectiveness. Each institution needs to plan and develop online learning classes in conjunction with discrete market research ${ }^{18}$; research that often requires high investment costs. The institution's management team also needs to establish the program framework and scope, including policies, procedures, mission and copyright requirements. Short-term and long-term operational plans are also needed to enhance academic and business activities.

\section{Learning Environment}

The online learning environment is a series of locations that may be real or virtual, where students may access online courses and resources, as well as communicate and receive assistance and assignments ${ }^{11}$. There are many elements involved in the functioning of the online learning environment such as interaction, accessibility, technical and course management. Effective online learning environments need interaction and collaboration among participants. Higher quality distance education classes appear to be linked to these factors. Widely recognized forms of interaction are student-student, student-instructor, and student-content. Easy access and effective navigation facilitates communication and learning activities in the online environment ${ }^{8}$. Many researchers identify technical support as having a significant role in delivering learning contents and transferring knowledge to online students. An effective course management system provides an important foundation by serving as a tool that allows instructors to create course content and conduct interactions with students ${ }^{7}$.

\section{Instructional Design}

Instructional design defines how a course is structured and can influence the learning environment. There are many elements that affect instructional design such as objectives clarification, quality of the contents, learning strategies, learning motivation, and learning assessment $^{18}$. Researchers describe objectives clarification as including a syllabus and learning 
pathways that must be provided to online students for successful course delivery ${ }^{22}$. Other researchers believe that strong contents can provide effective online education; various methods must be implemented to support online learning activities ${ }^{4}$. Objectives must also be clarified to motivate learning, as they are linked closely with online learning outcomes. Instructional design must provide a reliable and fair valuation mechanism to evaluate learning results ${ }^{13}$.

\section{Service Support}

Many researchers noted that service support influences students' and instructors' satisfaction and happiness in online education participation ${ }^{18}$. Training, help desk, and communication tools are grouped into the service support category. Training improves the ability of people involved in technology in online distance learning participation ${ }^{18}$. It is believed that establishing a help desk is the best way to assist online students ${ }^{4}$. Multiple researchers noted that communication tools enhance interaction between students and instructors as well as learning outcomes.

\section{Course Evaluation}

The evaluation process is essential to ensure that students enrolled in online distance learning meet all course requirements and objectives ${ }^{15}$. In order to objectively evaluate the success of online courses and their respective programs, a SWOT analysis can be an effective tool. A SWOT analysis is a tool that identifies the strengths, weaknesses, opportunities and Threats of an organization. Specifically, SWOT is a basic, straightforward model that assesses what an organization can and cannot do as well as its potential opportunities and threats

\section{Methods}

The purpose of this study is to identify challenges and generalize strengths, weaknesses, threats and opportunities, in managing online graduate construction management courses based on the responses of a sample population. The method is to take the information from an environmental analysis and separate it into internal (strengths and weaknesses) and external issues (opportunities and threats). Once this is completed, the SWOT analysis will provide a blueprint to determine what may assist the firm in accomplishing its objectives, and what obstacles must be overcome or minimized to achieve desired results. A survey, questionnaire or interview was the preferred methods to gather data on a broad range of issues. An advantage to this survey method of data collection is the ability for a rapid turnaround and ease of data collection. The method of distribution that was the most efficient, convenient, cost effective and timely was sending the survey via email. However, two respondents were interviewed via the telephone.

The survey population included construction management educational professionals who are currently working in an accredited online graduate construction management program at a college or university. Other participants included current and graduated students, and new industry professionals. This population was chosen as they had all been exposed not only to the various areas of the construction industry environment, but they also experience in the educational sector of construction as well. 50 surveys were distributed via email, 10 were 
received, and the data was collected. It is recognized that the number of respondents may have been affected by inaccuracy of contact information, or the potential candidates' willingness to participate. The data from the survey process is recorded in the figures below.

\section{Research}

The following sections display data collected from construction management professionals, administration, current students, and alumni. Following the survey and extrapolating the answers provided, a SWOT analysis was chosen as the tool to interpret the data. From this, further research analysis reveals both the positive and negative experiences of the faculty and students with regard to construction management online graduate programs.

\section{Strengths}

Current students and alumni attribute the success of online programs to a plethora of academic and personal strengths. For many individuals, achieving a Master's Degree is only a dream, but for those willing to put in the hard work and sacrifice, earning a degree can be a life changing accomplishment. Many graduates compliment their online program for expanding their perception of the construction industry from a local and regional view to a global perspective. As one respondent explained:

"Over the past couple of years I have been enrolled in the MCM program and feel as though I have been exposed to the larger scheme of the construction industry then as an undergraduate. I have had the opportunity to view the construction industry through an international viewing glass so as to broaden my outlook on how the construction industry is evolving and the changes that will be necessary in order to remain competitive. Advanced ideals of human resource management have allowed me to further grasp the concept of what customers and employees want and the methods needed to be able to deliver products and services of value to all involved."

Another strength to the online curriculum is the increased knowledge base and altered, or critical, thinking approaches that are applied to typical construction issues. In a survey by The Association of American Colleges and Universities, summarizing the findings of a national survey of business and nonprofit leaders say more than $75 \%$ of business owners want to hire individuals who demonstrate more emphasis in five key areas including: critical thinking, complex problem solving, written and oral communication, and applied knowledge in real-world settings ${ }^{24}$. Courses such as legal contracts and land development, allow students to view issues from different aspects of the same industry.

"Completing the MCM program has broadened my knowledge base and given me the tools to be a highly effective Construction Manager. From the beginning, Critical Analysis set the course for a positive experience in the program by familiarizing student with research tools and formal reports. If I ever need to know something about the construction industry, or anything else for that matter, I know how to do the research and present a proposal to my 
superiors if needed. The Joyner Library is a tremendous asset and helped me be successful in the MCM program.

The MCM program covered many valuable sources of information such as Building Information Modeling and augmented reality in Advanced Computer Applications in Construction, the importance of capitalizing on corporate knowledge in Human Resources and Training, utilizing Interactive Planning (IAP) to create more effective construction schedules in Advanced Applications in Construction Scheduling, capitalizing on cultural differences in the Global Management of Construction, understanding Quality Control Systems that help the Project Management Team meet owner expectations while keeping the project on time and on budget, and examining project delivery systems in Advanced Cost Estimating.

The two classes that influenced me the most were Land Use Management and Development and Legal Implications of Design and Construction. The active learning exercises in Land Use Management and Development engaged students to learn local zoning laws and encouraged relationship building with municipal employees. It was one of the best learning experiences I have ever encountered. The extreme value of information obtained in Legal Implications of Design and Construction will provide students a competitive edge in the construction industry by raising their awareness of contractual risk distribution.

Also a more in-depth structure was given as to how to build and/or restructure an organization so it operates at optimum efficiency. Strategies and approaches were also addressed as to how to address internal as well as external issues that arise within an organization. By having various counter methods of dealing with the various conflicts the most advantageous solutions to all parties could be obtained. I believe the MCM course has provided me with the essential tools to further advance my professional career both mentally and physically by providing a more indepth understanding of the construction industry as a whole."

Even with students' high praises regarding their professional development, a personal evolution is also a bounty to the success of online programs. However, despite the balance they find between work life, home life and school, online programs also present their own set of weaknesses which may limit the overall effectiveness of their efforts.

\section{Weaknesses}

According the administered small survey of graduate administrators, the weaknesses of an online graduate program, may prove cumbersome, but are currently manageable. One such weakness is the effort it takes to convey to the public that online programs are of equal educational quality as face-to-face programs. Communicating this message may be especially difficult with nonregionalized prospective distance education students.

"I am concerned with the term online learning class and the narrow concepts some people may have of this. I would suggest that anyone seeking to provide education to students not in their physical presence focus on the broader distance learning. Find methods and tools, which may or may not rely solely on internet technology, to overcome the distance. 
Though one educator noted how an educational institution might manage their weaknesses in the form of not only representation but outreach efforts as well. By reaching out to those interested in online programs, the college can assure them of the quality of their programs. This can be done through email correspondence or addressing telephone inquiries. For prospective students in regions beyond a reasonable distance from the institution, these representations of the online program and its credence will come by way of these messages and conversations.

Another hindrance to online graduate programs may be educating faculty about the importance of implementing distance education programs. Many faculty and administrators tend to be distinguished in their fields and very accustomed to the traditional systems of education. It is challenging to convince them that the ability to pursue alternative educational systems can benefit all the parties involved. One educator voiced,

"Often the focus of "difficulties" is with the tools we use in the educational process, and these are often highlighted by attempts at distance education. From my study and experience the three most significant difficulties for a program offering distance learning revolve around one basic theme, getting students into the courses. 1) Conveying the program quality to the public:

Distance learning has carried a stigma of poor educational value from the days of correspondence courses to today's diploma mills. While the allure of a watered down program to get a quick buck is tempting for even traditionally strong academic institutions, especially in more trying economic times, it is becoming evident that a tradition of quality and value will stand the test of time. Students may complain about the amount, and rigor of work required to obtain a quality degree but they clearly value its significance. Programs these days need to be able to convey to the public and potential students that the value of their in person and distance learning venues is equivalent. This is often more difficult for non-regionalized distance education, but an informed public will provide the client pool distance education.

2) Educating the Administration about market based educational programs: Academic Administrators tend to be former faculty moving up the corporate ladder. Unfortunately, while distinguished in their fields, they are often lacking basic education and experience in management principles. Operating for their entire careers within a highly socialized and regulated system, they often lack vision and ability to pursue alternative educational systems. This limits the ability of program directors to determine market needs and provide accessible, cost effective education.

Lastly, 3) Educating Faculty about market based educational programs: We have for a long time seen a strong US and world economy driving corporate profits and government tax dollar into significant research projects. Faculty get lax in the number of courses and student enrollments, focusing and relying more on the more prestigious research funding to maintain their positions.

As regional and global markets recede Academic institutions are forced to look to academic tuition to provide more of the funding model and faculty scramble to find students. Distance programs offer a needed boost to course enrollments but the faculty must adjust their perception of the student as a client rather than a necessary evil." 


\section{Opportunities}

The term "online education", should open a door containing an infinite amount of information, training, and success. The Internet has enabled innumerable technological advances and continues to break barriers between worlds. Opportunities in online education can be unlimited if institutions remain open to the possibilities. One such opportunity in providing graduate online courses would be the diversity of class topics in construction. Programs such as BIM applications, Estimating and Scheduling Interfaces can be used as tools to ensure success when searching for careers as they are used widely and frequently throughout. With so many specializations within the construction industry, such as engineering, development, demolition, sustainability and many others, online courses can provide students an in depth look within these fields to increase their understanding of the construction industry as a whole.

In addition to a wide range of courses, universities may be able to employ distance administration and faculty. With the ability to hold online meetings and collaborate projects from any location with an Internet connection, quality educational experiences can occur virtually everywhere. With widened geographic borders, increased enrollment may not be too far away.

"Spend time researching and then identify the limitations of your methods and tools. Examples are, 1) If you are located in the US and employ a synchronous learning tool, either don't market to Europe or plan to offer courses early (very) in the day; 2) If you are located in or have students in Alaska, a delivery platform that requires significant bandwidth is not appropriate.

For the Instructors, as long as success is defined by actual student learning, 1) Maintain your personal teaching style, 2) Maintain interaction between student and instructor, and 3) Maintain interaction between students. Technology is not an excuse for, and does not cover up a lax approach to education."

\section{Threats}

Even with so many benefits, there are still forces that threaten the success of distance education. One such threat is the concern for the quality of distance education. A popular stigma surrounding online programs is that students may receive a degree with minimal validity or recognition because it was obtained online. Reputations in the construction industry are a vital component of success. Without positive reinforcement for online graduate programs, the future of distance education may be at risk.

Another threat to the future of successful online programs is affordability. The cost of attending a public university rose $42 \%$ from 2000 to $2011^{25}$. The total cost of an online program can present some surprises depending on the residency status of the individual, the technological fees and resources, and the institution itself. In $2012,71 \%$ of college graduates graduated with student debt, with an average of $\$ 29,400$ in outstanding debt ${ }^{26}$. While earning a master's degree can significantly advance one's career and earning potential, students coming out of graduate school, both online and traditionally, can have a debt upwards of approximately $\$ 50,000{ }^{9}$. While some 
employers are willing to offer some tuition reimbursement for employees who are interested in professional development, that may be tempered by cost factors. Some online programs cost more per credit hour than out of state tuition costs for traditional programs. Nevertheless, one educator firmly stated his solution to overcome these threats;

"We seek to identify these as the key difficulties and manage them as opposed to overcoming them. Traditional academic governance and attitudes are well suited to the traditional academic model and do not necessarily need major overhauls. We do need to recognize that these are very different than what is required for distance education We need to seek ways to integrate the two. Understanding the differences, and expecting the two will not always mesh, will allow for quicker more appropriate resolutions."

\section{Discussion and Conclusion}

Over the years, a number of distance education theories have been proposed that seek to define its components. While every theory does not include all components of distance education, each focuses on specific aspects or interactions. This paper attempts to address the keys to success of online graduate construction management courses. Offering distance education programs, while presenting its own set of challenges, can provide a competitive advantage for those institutions that take steps to develop well-designed courses that meet the needs of the marketplace. Presenting this mode of education is likely to attract those who wish to continue their education without the immense time sacrifice that face-to-face instruction often demands.

Institutions cite issues such as the lack of funding to implement online programs and lack of personal technological expertise as major contributors to most problems. While research indicates that a major obstacle for online courses is the cost of providing the courses and technology that these programs require, it is crucial that institutions are open to the idea of allowing these types of programs a chance at success. When these obstacles are overcome, the success rate of these programs should significantly increase, and will prove beneficial to institutions choosing to implement them.

Many institutions however, have been able to implement and maintain successful online graduate programs that are just as effective as traditional education as measured by learning outcomes. When graduate programs that offer online courses have the commitment needed from the institution and from faculty, a productive learning environment and educational interactions are achievable. Focusing on building collaboration, discussion, and interaction is as critical if not more important in online courses than in face-to-face classes. It has been suggested in previous research, that "the swift achievements of information and communication technologies" will require "the design of new formats for learning and teaching and [will cause] powerful and farreaching changes of the learning-teaching process". Advancements in society and new demands in professionalism have brought that future to the present. A proactive and adaptable approach to graduate online construction management courses is the beginning of a bright future for institutions and future professionals alike. Embracing the new movement and delivering it with world class quality is the best way to ensure success. 


\section{Bibliography}

1. Allen, I. E. \& Seaman, J. (2005). Growing by Degrees: Online education in the United States, 2005. The Sloan Consortium. URL (last checked 17 June 2012)

http://sloanconsortium.org/publications/survey/growing_by_degrees_2005.

2. Arabasz, P. \& Bake, M.B. (2003). Evolving campus support models for e-Learning courses. ECAR Respondent Summary, March 2003. URL (last checked 28 Dec 2011)

http://net.educause.edu/ir/library/pdf/EKF/ekf0303.pdf.

3. Atalah, A., and Muchemedzi, R. (2006). "Improving enrollment in the Master of Construction Management Program at Bowling Green State University.” J. Profl. Issues Eng. Educ. Pract., 132(4), 312-321.

4. Bacsich, P., Bastiaens, T. \& Bristow, S.F. (2009). Reviewing the virtual campus phenomenon: The rise of large-scale e-Learning initiatives worldwide. Heverlee: EuroPACE ivzw. URL (last checked 19 Jan 2012) http://revica.europace.org/Re.ViCa\%20Online\%20Handbook.pdf.

5. Bilbo, D., Fetters, T., Burt, R., \& Avant, J. (2000). A study of the supply and demand for construction education graduates. [online] Journal of Construction Education, 5(1), 78-89.

6. Cheawjindakarn, B., Suwannatthachote, P., \& Theeraroungchaisri, A. (2012). Critical success factors for online distance learning in higher education: A review of the literature. Scientific Research, 3. doi: 10.4236/ce.2012.38b014.

7. Cruz, A. \& Implementation and Support Manager. (2010). Key success factors for eLearning implementation resulting from proper planning. URL (last checked 31 Dec 2011)

http://www.shiftelearning.com/key-success-factors-for-elearning-implementation-resulting-fromproperplanning/

8. Harasim, L. (2003). Elearning communities of practice for teachers. In the electronic classroom of tomorrow. Columbus, Ohio: EOS Publishing.

9. Khan, B.H. (2001). A framework for web-based learning. New Jersey, USA: Educational Technology Publication, Engelwood Cliffs.

10. Kuhl, A., Reiser, C., Eickhoff, J., \& Petty, E. M. (2014). Genetic counseling graduate student debt: Impact on program, career and life choices. Journal of Genetic Counseling, 23(5), 824-837. doi:10.1007/s10897014-9700-0

11. Lennon, J., Maurer H.: "Why it is Difficult to Introduce eLearning into Schools And Some New Solutions"; J.UCS 9,10, 2003.

12. Levitt, R. E. (2007). "CEM research for the next 50 years: Maximizing economic, environmental, and societal value of the built environment." J. Constr. Eng. Manage., 133(9), 619-628.

13. Masrom, M., Zainon, O. \& Rahiman, R. (2008). E-learning critical success factors: institutional and technological aspects. E-Learning Issues in Malaysian Higher Education, 49-63. 
14. Moore, M., \& Kearsley, G. (2005). Distance education: A systems view (2nd ed.). Belmont, CA: Wadsworth.

15. Musa, M.A. \& Othman, M. S. (2012). Critical success factor in e-Learning: an examination of technology and student factors. International Journal of Advances in Engineering \& Technology, 3(2), 140-148.

16. Pawlowski, J. M. (2002). Reusable Models of Pedagogical Concepts - a Framework for Pedagogical and Content Design. In Proceedings of ED-MEDIA 2002, World Conference on Educational Multimedia, Hypermedia \& Telecommunications.

17. Peters, O. (2002). Distance education in transition: New trends and challenges. Bibliotheks- und Informationssystem der Universitat Oldenburg.

18. Puri, G. (2012). Critical success Factors in e-Learning - An empirical study. International Journal of Multidisciplinary Research, 2(1), 149-161.

19. Schlosser, L. A., \& Simonson, M. (2009). Distance education: Definition and glossary of terms (3rd ed.). Charlotte, NC: Information Age.

20. Selim, H. M. (2007). Critical success factors for e-learning acceptance: Confirmatory factor models. Computers \& Education, 49(2), 396-413.

21. Simonson, M. (2012). Teaching and learning at a distance: Foundations of Distance Education. Boston, MA: Pearson.

22. Wands, M. \& Blanc, A.L. (2001). Critical Success Factors: eLearning Solutions. 2(3), URL (last checked 9 June 2012) http://www.internettime.com/itimegroup/crit_capp.htm.

23. Ward, S. G., \& White, M. (2015). THE GREEHEY SCHOLARS PROGRAM AS AN INNOVATIVE SOLUTION TO THE STUDENT DEBT AND EMPLOYMENT CRISIS OF RECENT GRADUATES. Academy of Educational Leadership Journal, 19(2), 159-172. Retrieved from http://search.proquest.com.jproxy.lib.ecu.edu/docview/1750973136?accountid=10639.

24. It Takes More than a Major: Employer Priorities for College Learning and Student Success. 2013. Washington, DC: Association of American Colleges and Universities and Hart Research Associates.

25. "Price of Attending an Undergraduate Institution." The Condition of Education - Postsecondary Education - Finance and Resources - Price of Attending an Undergraduate Institution - Indicator May (2015). National Center for Educational Statistics, 2015. Web. 02 May 2016.

26. "Student Debt and the Class of 2014." Student Debt and the Class of 2014 (2015): n. pag. The Institute for College Access \& Success. 27 Oct. 2015. Web. 